\title{
ANOTASI BIBLIOGRAFI MANFAAT TEKNOLOGI INFORMASI DALAM MEDIA PEMBELAJARAN \\ Oleh
}

\author{
Ahmad Maulana \\ Email: 1910111210013@mhs.ulm.ac.id \\ Program Studi Pendidikan Sejarah Fakultas Keguruan dan Ilmu Pendidikan \\ Universitas Lambung Mangkurat \\ Banjarmasin
}

Susanto, H., \& Akmal, H. (2019). Media Pembelajaran Sejarah Era Teknologi Informasi (Konsep Dasar, Prinsi Aplikatif, dan Perancangannya).

Buku media pembelajaran sejarah didalamnya membahas Tentang suatu perkembangan teknologi informasi yang berdampak pada kehidupan dan juga dalam pembelajaran di sekolah. Perkembangan inovasi pada media pembelajaran sejarah di era teknologi informasi dapat bermanfaat untuk memperbaiki kualitas pembelajaran sejarah. Penggunaan sebuah media yang berbasis daring dalam pembelajaran sejarah sangat berguna di era teknologi informasi khususnya dalam komputerisasi dan mobile smartphone. Buku ini juga memberikan banyak materi dan penjelasan untuk menciptakan media pembelajaran sejarah yang baik di era teknologi informasi. berbagai makna dari konsep media pembelajaran sejarah, prinsip aplikatif pembuatan media pembelajaran sejarah berbasis teknologi informasi, hingga merancang media pembelajaran sejarah berbasis teknologi informasi dapat dijadikan sebagai pedoman atau petunjuk bagi guru dan para calon tenaga pendidik.

Susanto, H., \& Akmal, H. (2018). Efektivitas Penggunaan Aplikasi Pembelajaran Berbasis Mobile Smartphone Sebagai Media Pengenalan Sejarah Lokal Masa Revolusi Fisik Di Kalimantan Selatan Pada Siswa Sekolah Menengah Atas. HISTORIA: Jurnal Program Studi Pendidikan Sejarah, 6(2), 197-206.

Jurnal ini membahas tentang keefektifan aplikasi dalam media pembelajaran melalui mobile smartphone dan juga digunakan sebagai media pengenalan sejarah lokal masa revolusi fisik di Kalimantan Selatan. Jurnal ini memakai motode penelitian kuantitatif dengan desain pre-experimental one-group pretest-posttest yang menguji efektivitas media dengan membandingkan pemahaman siswa sebelum dan sesudah diberi treatment. Pada jurnal tersebut perkembangan teknologi informasi di era abad ke-21 semakin berkembang pada kehidupan masyarakat karena perkembangan tersebut 
menjadi alat atau fasilitas dalam membantu meringankan pekerjaan. Terobosanterobisan yang baru dalam teknologi informasi menciptakan hal-hal baru di berbagai bidang. Begitu pula pada bidang pendidikan, teknologi informasi seperti PC, laptop, bahkan mobile smartphone sudah digunakan oleh guru maupun siswa sebagai alat atau media dalam pembelajaran. Adanya pemutakhiran kurikulum dalam dunia pendidikan Indonesia dari Kurikulum Tingkat Satuan Pendidikan (KTSP) menjadi Kurikulum 2013 (K13) membuat teknologi informasi menjadi sebuah komponen yang penting pada media pembelajaran.

Susanto, H. (2020). Profesi Keguruan.

Pada buku profesi keguruan membahas tentang informasi, evaluasi dan tindaklanjut bagi seorang guru dan para calon guru untuk memberikan pengalaman belajar serta pemahaman materi yang akan diberikan. Pengembangan profesi guru, terdapat dari berbagai aspek yang dapat dikembangkan, antara lain pengembangan aktivitas instruksional, pengembangan karir, dan pengembangan aspek keprofesian. Aspek yang dapat dikembangkan dari aktivitas instruksiona, yaitu desain pembelajaran, media pembelajaran, strategi pembelajaran, sumber belajar dan lain sebagainya yang berhubungan dengan aktivitas pembelajaran di kelas maupun di luar lingkungan kelas. Pada aspek keprofesian, perkembangan profesi guru dapat dilihat dari sejarah pendidikan Indonesia. Penyiapan untuk calon guru mulai mengalami perkembangan dari struktur persekolahan, kurikulum dan kebijakan terhadap pendidikan guru. Peningkatan peran organisasi profesi guru dapat bermanfaat dalam upaya membangun kemandirian dan kredibelitas profesi guru. Buku ini juga memuat undang-undang tentang guru dan dosen yang dapat dijadikan sebagai acuan atau pedoman dalam perkembangan profesi keguruan

\section{Simpulan Konseptual Anotasi Bibliografi}

Media pembelajaran merupakan alat yang dapat menyampaikan atau menyalurkan pesan dari seorang individu atau kelompok kepada individu atau kelompok yang lain, dengan tersumber secara matang dan tepat dalam penyampaian agar dapat menciptakan suasana lingkungan yang aktif, efektif dan efisien dalam melakukan kegiatan pembelajaran. Konsep media pembelajaran sejarah, prinsip aplikatif pembuatan media pembelajaran sejarah, dan rancangan media pembelajaran sejarah yang memiliki manfaat dalam media pembelajaran pada perkembangan teknologi informasi. Perkembangan teknologi informasi juga berdampak dalam proses pembelajaran di sekolah. Inovasi yang mulai dikembangkan untuk meningkatkan media pembelajaran bermanfaat dalam memperbaiki kualitas pembelajaran. Penggunaan sebuah media yaitu mobile smartphone sebegai alat bantu pada 
media pembelajaran berguna untuk memudahkan siswa mencari berbagai sumber informasi dalam pembelajaran.

Manfaat aplikasi sebagai alat media pembelajaran digunakan melalui mobile smartphone yang berguna sebagai media pengenalan sejarah lokal. Perkembangan teknologi informasi di era abad ke-21 menciptakan sesuatu hal yang baru sepeti PC, laptop, bahkan mobile smartphone. Pemanfaatan serta hubungan media pembelajaran di era teknologi informasi membuat sebuah kemajuan dalam dunia pendidikan Indonesia yaitu dengan memanfaatkan teknologi informasi sebagai sebuah komponen yang penting bagi media pembelajaran. Manfaat dari perkembangan teknologi memunculkan perkembangan pada profesi guru yang dimana guru adalah seseorang yang dapat menguasai bahan dan materi pelajaran serta menyusun strategi pembelajaran yang tertuju pada rencana dan media pembelajarannya. Kualitas pendidikan menjadi salah satu faktor yang mendukung seorang guru tetapi kualitas profesional guru menjadi sebuah hal yang utama dan sangat dominan dalam melakukan pembelajaran. Media pembelajaran dapat berkembang dari masa ke masa karena perkembangan teknologi informasi mulai memasuki perkembangan yang baru dengan model-model dan media yang sudah bertransformasi sangat canggih. Hal tersebut dapat menjadi suatu motivasi dalam perkembangan pendidikan Indonesia yang akan menggunakan media pembelajaran berbasis pada teknologi informasi 